\title{
Sun and beach tourism, senior citizens and accessibility: a study at the coast of the city of João Pessoa, $\mathrm{PB}$
}

\author{
Priscila Fernandes Carvalho Melo ${ }^{\mathrm{a}}$
}

\author{
Adriana Brambilla ${ }^{\mathrm{b}}$
}

\section{RESUMO}

The public of senior citizens is growing, due to the greater concern with physical and mental health. Tourism is one of the ways through which this group enjoys their free time, especially the Sun and Beach Tourism, which provides them different kinds of activities. This work aims to answer the following research question: How senior -friendly are the beaches of the João Pessoa coast in terms of accessibility? To meet this research objective, bibliographic, documentary and descriptive research were carried out, and a qualitative analysis was conducted, based on field research, on-site observation and the application of a checklist as the methodological procedures. Through the reports obtained from the on-site observations, it was clear that the urban beaches, i.e. those closest to large urban centers, are more accessible than those further away from the urban centers. However, none of the studied beaches fully met the accessibility criteria outlined in NBR9050/2015. As future contributions, an accessibility guide to the main beaches of João Pessoa will be produced, based on the information obtained, in order to provide information on accessibly for interested parties, including visitors, the public sector and the tourist trade.

\section{PALAVRAS-CHAVE}

Sun and Beach Tourism

Senior Citizens

João Pessoa 


\section{INTRODUÇÃO}

Sun and Beach Tourism, according to Brazil (2008), covers tourist activities related to recreation or resting on beaches. It an important segment that attracts a huge number of national and international tourists to Brazil. However, one of the major obstacles to the development of this segment is the lack of accessibility to the tourist attractions, as certain characteristics must be in place in order to provide adequate conditions for visitors to the location.

This study focuses specifically on senior citizens, i.e. those aged sixty years and older, who travel to sun and beach tourism destinations. The interest in this group of visitors is justified by the change in the Brazilian demographic profile in recent decades, with a perceptible increase in the life expectancy of the Brazilian population (Brasil, 2016). This increased life expectancy is due to several factors, such as technological improvements, better living conditions and medical advances, among others.

These improvements have enabled people over sixty to fully enjoy many tourist activities (OLIVEIRA, 2001); however, Evangelista, Brambilla and Vanzella (2019) warn that despite being in good health, elderly visitors require special care and adaptations if they are to have full access to the tourist attractions.

Tourist activities allow the elderly to break out of the routine, get to know new places and new people, and enjoy beneficial experiences that will promote physical and mental health. Thus, many Brazilian regions with tourist potential are sought by this sector of the population. The Northeast of Brazil, due to its warm climate all year round and a extensive coastline, has strong appeal to this customer group, and is the most popular destination for senior travelers (BRAZIL, 2014). The city of João Pessoa benefits from this demand as its coastline makes it an important tourist destination, with beaches of unique beauty, attracting visitors and generating high touristic potential, especially among senior travelers, the emphasis being on Sun and Beach Tourism.

In view of the demographic changes with regard to senior citizens in Brazil and globally, and their impacts on the Sun and Beach Tourism, this work aims to answer the following research question: How senior -friendly are the beaches of the João Pessoa coast in terms of accessibility?

To answer this question, the specific objectives were: to make a list of the beaches of João Pessoa; to draw up and apply a checklist, as a research instrument, to determine the accessibility for senior citizens group to the attractions mentioned in this study; to elaborate a comparative report of the analyzed beaches in terms of senior-friendly accessibility conditions, to create photographic records of the accessibility conditions, and to provide advice where necessary.

The justification for this work is that it introduces important discussions on contemporary themes, such as accessibility and the importance of senior travelers as potential consumers of Sun and Beach Tourism.

\section{THEORETICAL REFERENCE}

Demographic changes in a population affect many sectors of society; the increased life expectancy of the Brazilian population has led to several needs that must be met. Population aging and increased life expectancy are issues inherent to the Brazilian scenario, since Brazil, like many countries, has shown a significant growth in the elderly population - defined in the first article of the Statute of the Elderly as comprising people aged sixty years or over (BRASIL, 2014). Supporting this statement, Vanzella (2019) states that by 2030, there will be about 41.5 million Brazilians aged 60 or over, and by 2060 the elderly population may reach 73.5 million.

Although the subject of aging has already been addressed by several studies, changes in the way we view and understand the behavior of so-called senior citizens have demanded further studies, seeking to understand and fulfil the needs of this group, as in addition to living longer, senior Brazilians are also traveling more frequently. Therefore, tourist destinations must improve the quality of their touristic products and services (ALVES, 2016)

According to Brasil (2008), tourism is one of the activities most in demand, as a leisure opportunity, among senior citizens. However, among the tourism segments, Sun and Beach Tourism - defined as the 
segment related to entertainment, contemplation or resting on beaches - is sought by the majority of senior travelers, who enjoy the benefits of water, sun and warm weather.

Senior citizens who engage in Sun and Beach Tourism become consistently healthier, allowing them to engage in many tourist activities. However, this group also requires special attention (BRAMBILLA, VANZELLA and BAPTISTA, 2012), particularly when it comes to the accessibility of these locations, one of the major obstacles to the development of this kind of tourism.

According to ABNT (2015), accessibility is understood as the possibility and condition of reaching, perceiving and understanding for the safe and autonomous use of spaces, urban equipment, buildings, means of transportation, as well as other services and facilities open to the public, of public, private or collective use, both in urban and rural areas, by people with disabilities or limited mobility.

Thus, accessibility in tourism means enabling people with disabilities or limited mobility to participate in touristic activities. The offer of hospitality to senior tourists, respecting their wishes and desires in order to exceed their expectations, supports decision-making, since senior citizens establish their own criteria when choosing a tourist destination. Consequently, a destination with good accessibility is more likely to attract senior travelers (RUSCHMANN e SOLHA, 2012)

In order to attract senior travelers, tourist destinations must offer infrastructure and organization, and in particular, good accessibility. Therefore, the importance of accessibility management and planning for Sun and Beach Tourism segment should be emphasized. Tourism related sectors of society must conduct studies in order to discover and monitor accessibility actions carried out by tourism localities that offer Sun and Beach Tourism as an attraction, and to define strategies that will enable broader inclusion of all, in the tourist activities of the region.

Public tourism policies must promote tourism development through basic actions for the sector (LOHMANN and PANOSSO, 2012). The basic public policy actions for tourism and accessibility include infrastructure issues, such as non-slip sidewalks without cracks, accessibility ramps with handrails, accessible routes, parking close to routes and in sufficient quantity as established by law, among other aspects. The lack of these aspects to meet the needs of senior traveler may prevent their access, or even result in accidents (MELO, VANZELLA and BRAMBILLA, 2019). This obstacle may, according to Beni (2001), is harmful to the tourism sector, and tourist structures at present do not offer good conditions of accessibility to the community. (SHIMOSAKAI, 2016).

\section{METODOLOGY}

This study is characterized as bibliographical, documentary and descriptive research, with qualitative analysis through field research, on-site observation and the implementation of a checklist. The bibliographic research was carried out in books, and national and international scientific articles addressing issues related to senior citizens, aging, tourism, accessibility, and the João Pessoa coastline, in order to gain a better understanding of the subject.

The document research involved a careful reading of the legislation regarding accessibility and elderly people, including NBR 9050 (ABNT, 2015), the Statute of the Elderly (Law Number 10,741/2003 and the respective Decree 5,934/2006), legislation on priority of assistance to the elderly (Law 10,048/2000), the promotion of accessibility for people with disabilities or limited mobility (Law 10,098/2000) and the $\mathrm{Na}$ tional Policy for the Elderly (Law 8,842/1994). In addition, the following documents were consulted: United Nations Principles for Older Persons (Resolution 46/91 of the United Nations General Meeting, December 16, 1991); Statute of the Elderly; Decree 5,296 of 2004; Decree 5,934 of 2006; Law 8,842 of 1994 and Law 13,146, of 2015. This background research was essential for the preparation of the checklist, which was used as a guide to verify the conditions of accessibility of the visited places. Descriptive research, in turn, is characterized by the goal of identifying and describing the analyzed object (MALHOTRA, 2011), without any intention of testing hypotheses.

The study site was limited to the João Pessoa coast, comprising the beaches of Bessa, Manaíra, Tambaú, Cabo Branco, Seixas, Penha, Praia do Sol and Barra de Gramame, since these attract most part of the 
tourist flow compared to the other options in the sector.

In order to define the beaches for inclusion in study, the Sun and Beach segment is understood to include maritime, fluvial, lake and artificial beaches. This study considered maritime beaches as "environments bordering the sea which are influenced by tides and waves. They are dynamic environments with constant changes in their physical and biological attributes" (BRASIL, 2008).

A survey was conducted with the Tourism Office of the municipality of João Pessoa (SETUR) and the Paraíba Tourism Company (PBTUR), to collect information about the beaches to be analyzed.

Aiming to raise issues related to the expression accessibility, a checklist was drawn up, identifying the beaches and their respective attractions, date and time of the checks, and all the items to be observed during the research. This checklist - composed of 68 items was intended to analyze all the aspects needed for elderly people to enjoy these tourist elements independently and safely.

The preparation of the research instrument was based on the guidelines for tourism enterprises and attractions for senior travelers of the Manual de Dicas Para Atender Bem Turistas Idosos (Manual of Tips for Serving Elderly Tourists) of the Ministry of Tourism, the United Nations principles for Older Persons, adopted by UN General Assembly Resolution 46/91 of December 16, 1991 and the Decrees and Laws concerning the Statute of the Elderly. The following options were offered in order to complete the checklist: "compliant" (C), when the analyzed item met the requirements; "noncompliant" (NC), when the analyzed item was not in accordance with the accessibility requirements and "not applicable" (NA), when it was not possible to include this analysis.

The checklist also included a blank space for the researcher's remarks, since the observation technique was very useful. To gather other results, photographic records were also made, to better exemplify the analyses, as a photograph can show the information in a clearer way, supporting the cataloging of the research data. "These records will allow more detailed analyses, as they provide more objectivity and credibility, as an mage provides tangible proof of the existence of a cer- tain phenomenon" (MENDONÇA, BARBOSA, \& DURÃO, 2007). After each visit, a diagnosis of the results obtained in the checklist was carried out, to support the accessibility analysis of the attractions of the coastline studied.

Other complementary activities related to the project were carried out, such as participation in seminars focused on accessibility, which supported the understanding of the studied expression and its scope. Developing accessibility projects also involves empathy, to better understand the needs, fears, desires and anxieties of the senior travelers, providing more comfort and quality of life through the promotion of a more accessible and personalized kind of tourism designed for this group.

Weekly meetings were held during this research, to check how the research was going, and to ensure it was keeping to the established schedule. The meetings were to provide guidance on written works with a view to their publication at congresses related to Tourism, Aging, senior citizens and accessibility.

\section{RESULTS}

The research was conducted from August 1, 2018 to July 31, 2019 on the beaches of Cabo Branco, Tambaú, Penha, Seixas, Praia do Sol, Barra de Gramame, Bessa and Manaíra, and the target group consisted of senior citizens who engage in activities related to the Sun and Beach Tourism segment.

To meet this demand, this research was supported by the PIBIC (Institutional Program for Scientific Research Scholarships), which supports scientific research through the granting of scholarships, enabling the student - with the guidance of a qualified researcher - to learn new techniques and research methods. The PIBIC also offers a scholarship for researchrelated expenses, which was used transportation to the beaches analyzed, and to purchase materials for this analysis. The project was carried out within the scope of the Tourism Culture and Studies Group (GCET), in 
which the authors participate as researchers.

The data collection instrument - the checklist (sample in Appendix 1) - included the following items: tourist information points; access related features such as sidewalks, crosswalks, paving, steps, ramps, obstacles and other facilities; communication and signage; parking; restrooms; accessible seats, phone booths and access to the beach. The results are described below, arranged by beach:

a) Cabo Branco: One of the most well known and most popular beaches, due to its proximity to the urban center, and the many hotels, bars, restaurants, convenience stores, and other facilities. It has a wide sandy strip, where activities take place in the mornings and late afternoons. Accessibility is visible all along the beach, with ground-level signage on pedestrian crossings and lowered curbs, in accordance with standard ABNT NBR 9050. Of all the beaches analyzed, Cabo Branco has the best vertical and ground-level signage indicating parking spaces for disabled people and senior citizens (Figure 1: in the appendix). However, these parking spaces are not on an accessible route, and the dimensions are narrower than the $1.20 \mathrm{~cm}$ recommended in ABNT NBR 9050 to allow the driver or passenger with disabilities to get out of the vehicle safely.

It is also important to mention that, of the beaches surveyed, Cabo Branco is the only one that has a mobile ramp for wheelchair access to the sea. However, this access is only available on Saturdays and only on a small section of the beach. This ramp was provided through a social project; AC cidadão, which offers accessibility for the general public in a partnership with the João Pessoa municipality. This is a very important action, as it is related to the social inclusion of people with limited mobility; however, the vast majority of tourists do not have access to this information, preventing the engagement of a larger number of senior travelers with limited mobility.

b) Bessa: This is one of the largest beaches on the $\mathrm{Pa}$ raíba coast. It is situated between the Intermares beach, which belongs to the municipality of Cabedelo/PB, and the Manaíra beach, in João Pessoa/PB. As it is in a neighborhood with a many bars, restaurants, drugstores, supermarkets, banks, gas stations, among others, the flow of tourists has increased significantly in the region.

In relation to Sun and Beach Tourism and accessibility for senior citizens, the promenade along Bessa beach has non-slip and anti-vibration paving. It is over $1.20 \mathrm{~m}$ wide, but there is no tactile paving (Figure 2: in the appendix) for visually impaired people. There are lowered curbs in some sections with crosswalks, but in other sections, the curbs are irregular, with differences in height of more than $5 \mathrm{~mm}$, and unmarked crosswalks. The area also lacks toilets and tourist information points.

Despite attracting many tourists, the beach has a lack of accessibility, which could cause discomfort to tourists or visitors.

c) Manaíra: The visit to Manaíra beach was conducted in two stages, in order to analyze the entire beach. The beach starts at Gameleira Square, where the "Saudação ao sol" (Salute to the Sun) monument, by the sculptor Erickson Britto, is located, and ends just after one of the city's shopping malls located on the sea front. Thus, the beach is situated between Bessa and Tambaú beaches. Along the Manaíra beach promenade, the paving is non -slip, but vibrates. This can make access a little more difficult for elderly people with limited mobility, whether temporary or permanent, or for wheelchair users or people using crutches or walking sticks. Access to the beach is a major difficulty, due to the presence of steps, which reduces the number of visitors to this beach. Other negative aspects related to accessibility are the lack of a tourist information point, and the presence of guides for wheelchair users but without any pedestrian 
crosswalk (Figure 3: in the appendix). Tourists are directed to the tourist information point at Tambaú beach.

\section{d) Tambaú:}

Located between the beaches of Manaíra and Cabo Branco, this is where one of the most important hotels in the history of João Pessoa is located, the Tambaú Hotel, marking the starting point for the urbanization of the coastline. Like Cabo Branco, Tambaú is also a very busy urban beach, providing a wide range of activities and services.

Among the items on the checklist, there is a tourist information point, located at the Tambaú Tourist Center PBTUR Shopping mall on Tambaú beach, which provides information about cultural events taking place in the city, the main bars and restaurants offering regional, contemporary, and other types of cuisine, craft markets, sightseeing tours and other services.

However, it was noted that the employees do not receive specialized training to assist senior tourists, i.e. the training is not differentiated for this age group, and this could affect the quality of services provided, according to the Ministry of Tourism (2016).

To check whether Tambaú beach offers accessibility for the senior people, aspects of accessibility were analyzed. It was noted that the sidewalk is wider than 1.20 $\mathrm{m}$, providing comfort for everyone who walking or performing physical activity, with separate lanes for pedestrians, cyclists, rollerbladers and skateboarders. The surface of the sidewalk surface is in a good state of repair, with non-slip, anti-vibration paving, allowing for safe, comfortable walking. The entire sidewalk line has tactile paving (Figure 4: in the appendix); according to ABNT NBR 9050 (2015), this is paving characterized by a different texture in relation to the adjacent floor, to facilitate movement visually impaired people. In some cases, associated with the tactile paving, there is the hazard warning tactile paving, which signals the existence of an obstacle for sight impaired people.

The crosswalks at Tambaú beach are painted, and in some cases protruding strips were seen, but none of the crosswalks has a lighting system. In regard to signage, there was only indication of accessibility through the international access symbol, with lowered paving and hazard warning tactile paving.

In some cases, there were non-accessible lowered curbs, with differing heights of approximately $5 \mathrm{~cm}$ (Figure 5: in the appendix), making them difficult for persons with disabilities to negotiate. According to ABNT NBR 9050 (2015), differering heights of more than $15 \mathrm{~mm}$ should be considered as steps, and indicated as such with signs.

Along the sidewalk there are spaces to access the beach, but these spaces are not considered accessible for senior tourists with limited mobility. There are no accessible steps or ramps in these spaces. It was also seen that tactile paving diverts pedestrians away from obstacles along the access route, following the guidelines of ABNT NBR 9050. Some of the obstacles include garbage bins attached to the poles, and telephone booths. However, there is a distance of $70 \mathrm{~cm}$ from the obstacles to the tactile paving, to prevent visually impaired people from bumping into them (Figure 6: in the appendix). According to ABNT NBR 9050 (2015), parking spaces should have a minimum circulation space of $1.20 \mathrm{~m}$ to help the disabled driver or passenger get out of the vehicle; there should also be vertical and ground -level signage to enable the parking spaces to be easily identified, and where possible, they should be along accessible routes. In the inspection carried out at Tambaú beach, it was seen that there are no ground-level signs. All along the beach front, only one sign for disabled parking was seen. There were no ground-level signage in the parking area allocated for senior citizens; there was no minimum circulation width, and the spaces were situated next to a busy road.

Another important issue is the reference modules (R.M.) intended for wheelchair users (W.C.U.), which, according to Brazilian Standard NBR 9050 (2015), must have a protrusion of $0.80 \mathrm{~m} \times 1.20 \mathrm{~m}$. Following these recommendations, two spaces were found with benches and parking for bicycles that could be used by wheelchair users, as they are of the required width: 1.45 $\mathrm{m}$ and $3.30 \mathrm{~m}$ wide, respectively. The benches are 45 $\mathrm{cm}$ high, making them more accessible than the benches on the beach, which are only $35 \mathrm{~cm}$ high. This difference affects the physical conditions of tourists, especially the senior tourists, who may find it more difficult 
to sit down and stand up when the seats are lower. For tourists with a disability or limited mobility, Tambaú beach does not offer any facilities such as ramps to allow sea bathing, or amphibious chairs with tutors trained to assist this kind of public.

d) Seixas: located between the beaches of Cabo Branco and Penha. Despite receiving a large flow of visitors, it does not have good accessibility conditions, and public policies for tourism need to be implemented here. Unfortunately, Seixas beach does not meet the accessibility requirements included in the checklist. Given that it is included in the tourist route, due to its natural beauty, the nearby coral reefs of Picãozinho, and the Paraíba Aquarium where tourists can learn more about marine life, the problems of accessibility should be more seriously addressed by the public sector and the tourist trade.

e) Penha: known as the most religious-focused beach in João Pessoa, this is where the Nossa Senhora da Penha (Our Lady of Penha) Sanctuary and Chapel are located, a space where mass is held, and which is visited each day, by tourists and devotees who live in the city and come to make their petitions and give thanks. There is an intense flow of people, especially in November, when the Nossa Senhora da Penha pilgrimage takes place. Accessibility is therefore essential, for enabling autonomous and independent access for all.

Applying the checklist, it was seen that the beach does not have chemical toilets, access ramps, tactile paving, tactile maps or adequate signage, making this a destination that does not meet the minimum accessibility requirements.

Therefore, Penha beach cannot be considered accessible, and public policies are needed to improve the infrastructure and accessibility, both for tourists and the local community.

f) Praia do Sol: Praia do Sol is one of the last beaches on the João Pessoa coastline, bounded by the Mangabeira river to the north, and the Gramame river to the south.

Applying the checklist, it was found that the beach has no accessibility, as none of the items of the research instrument was seen at the beach. It became quickly apparent that the route to the beach itself is not very accessible, as it is down a bumpy road with lots of potholes and cracks.

A lack of cleanliness was also observed, with garbage bags left lying around, including in the mangrove. Despite its natural beauty, which is much appreciated by tourists and visitors, it cannot be considered accessible for senior citizens due to the lack of minimum conditions that would enable a good experience.

g) Barra de Gramame: similar to Praia do Sol, with characteristics that include natural beauty but a lack of infrastructure. This is where the Gramame River meets the sea water, providing a unique landscape.

But despite its picturesque scenery and unique experiences, such as crossing the river to enjoy the local cuisine, kayaking and paddle-boarding, the access route to the beach, and the lack of infrastructure that meets the recommendations of standard ABNT 9050, make this beach an inaccessible tourist attraction for senior citizens and those with disabilities or limited mobility.

\section{PRACTICAL IMPLICATIONS}

As an empirical investigation, this study conducted a field research which, according to Kaiser (2006), is an essential stage for analyzing social issues. Based on reports and the field research, this study aims to produce and promote an accessibility guide to the beaches of João Pessoa, in partnership with the Paraíba Tourism Company (PBTUR), which will contain information for all kinds of visitors, but particularly senior citizens and the tourist trade. The guide may be used by tourists and visitors seeking to find out whether a tourist attraction is accessible.

It is hoped that through this survey, the João Pessoa Municipality and the Paraíba State Government, along with the GCET, will be able to find solutions for improvements, observing the following recommendations:

Cabo Branco, Bessa, Tambaú, and Manaíra beaches, despite being meeting most of the accessibility items on the checklist, need further structural developments, such as the placement of vertical and ground-level signs for parking of senior citizens and disabled persons, visual and Braille signage, tactile maps, information signs so that everyone can have equal access 
to information, accessible toilets, ramps with suitable inclination, and handrails, thus providing greater safety for disabled and senior citizens. Access ramps to the sea and amphibious chairs for senior and disabled people should also be included. Audible and light signals are needed on the pedestrian crosswalks, and the curb levels should be checked, to ensure they meet ABNT standard NBR 9050/2015.

Regarding the Seixas, Penha, Praia do Sol and Gramame beaches, the implementation of more complex projects is imperative, as they do not have the minimum infrastructure features to offer senior tourists and visitors the necessary autonomy and independence to safely enjoy these beaches.

For Penha beach, we therefore propose the implementation of structural development projects, in particular, the installation of adequate signposting at the main access points, such as the steps, the chapel/ sanctuary, the observation deck, and the road leading to the beach. A tactile map should also be installed. There is a need for adequate parking for visitors, with places for senior and disabled people, according to ABNT standard NBR 9050, as the current parking spaces are located on a soccer field, and parking near the chapel is disorderly, with the steps making it difficult for cars and pedestrians to circulate. As it is a tourist site, the steps, which are cracked an in a poor state of repair, should be restored to their original form. The observation deck, also one of the most visited spots on Penha beach, also requires investments in the physical structure, to make this environment more attractive and offer better conditions for visitors. The construction of accessible toilets and the implementation of a ramp, with adequate inclination and a handrail, are also necessary.

Regarding Praia do Sol and Barra de Gramame beaches, Sun and Beach Tourism will only be fully enjoyed if public policies are implemented to improve the areas e.g. adequate access routes, signposting, parking for cars, vans and tourist buses, places for storage of garbage to preserve the environment, chemical toilets, access ramp, information points for tourists, and nautical activities in partnership with the private sector, among others. Some of the items on the accessibility checklist were not met, as there are no access ramps for wheelchair users, the parking lot is improvised, and amidst vegetation, there are no specific places for senior or disabled people, and there are information points for tourists with qualified staff to assist visitors. These beaches therefore require public policies aimed at developing responsible tourism, preserving nature, and offering comfort and safety to tourists, visitors and the local population.

Finally, Seixas beach is similar to Praia do Sol and Barra de Gramame beaches in terms of regarding infrastructure, the only difference being the road access to the beach, which is well signposted and in good condition. However, despite the easy access and tourist spots included in the João Pessoa's tourist routes, it does not have adequate accessibility, and public infrastructure works are required.

Based on our research, it was possible to analyze the issues related to accessibility on the beaches of João Pessoa, with very little expense compared to other activities, making this type of analysis feasible for other beaches of the region, or in other states, since the analysis was based on the current standards. Therefore, other locations can and should replicate this research to highlight the accessibility conditions, allowing more people to enjoy the autonomy and safety of Sun and Beach Tourism, which is present throughout the Brazilian coastline.

Another practical implication of this study was that it fosters discussion on the accessibility of the senior citizens to the Sun and Beach Tourism, aiming to support reflection on this theme and highlighting the possible interactions with other researchers involved in themes related to aging, accessibility and tourism. In 2018 , in order to foster discussion on the theme, we started participating in congresses and work presentations, such as the presentation of the work developed 
on Sun and Beach Tourism and accessibility for senior citizens at the VI FCGTURH - Scientific Forum on Gastronomy, Tourism and Hospitality at UNIVALI - Balneário Camboriú - SC in November/2018, and a presentation of the same work to veteran students and experts from the Federal University of Paraíba - UFPB in December/2018. In 2019, we developed an article on the accessibility of Tambaú beach-PB, which has already been submitted for analysis by a journal, and another article on Penha beach, the most religiousfocused beach in João Pessoa-PB, which was submitted to the the CIEH (International Conference on Human Aging).

Promoting the study of the senior citizens and tourists accessibility in the Sun and Beach segment is, therefore an action that aims to create conditions that will enable senior citizens to take part in tourist activities and, in a broader sense, to be integrated in society, helping them to remain active.

The study enabled students involved in the project, teachers of the Tourism and Hospitality Department (DTH - UFPB), researchers from other institutions, and the community in general to have a perspective focused on the needs of the senior citizens, and a concern for inclusiveness of all kinds of people in tourist activities.

\section{FINAL CONCLUSIONS}

Sun and Beach Tourism for the elderly is a market segment that helps increase jobs and provides working conditions, as tourist destinations must offer, in addition to infrastructure and attractions, a range of professionals to properly host, guide and assist visitors.

Thus, quality assistance to tourists, with good infrastructure conditions, supports the development of tourism and, consequently, offers better conditions for the local population when it comes to infrastructure, safety and leisure activities.

Therefore, it can be seen that at most of the urban beaches, i.e. those closest to large urban centers, such as Cabo Branco, Tambaú, Manaíra and Bessa, have a greater degree of accessibility compared to beaches further away, such as Seixas, Penha, Barra de Gramame and Praia do Sol. However, none of the studied beaches fully meets the accessibility conditions recommended in standard NBR9050 / 2015.

The beaches of Cabo Branco, Tambaú, Manaíra and Bessa must therefore put measures in place to meet ABNT NBR 9050 and offer autonomy and independence to tourists and visitors. Although there have been some recent renovations on these beaches, there is a lack of interaction among the areas involved in the planning process, causing failures that could be avoided with adequate communication.

Investing in accessibility for tourists will foster the development of localities. The participation of the local community, the government through public policies, and the private sector, will support the creation of a tourist demand, with the simultaneous consumption of goods and services that does not exclude people, i.e. making the tourist destination viable as a tourist product.

According to Evangelista, Brambilla and Vanzella (2018), accessibility is an interesting topic, not only for disabled people, but for everyone, as anyone can experience mobility difficulties at certain times in their lives. Hence the importance of considering the needs of all types of users when designing projects related to public policies.

It is important to emphasize the need for public policies to promote accessibility, as tourists may require differentiated assistance. To that end, public agencies and private businesses must comply with a number of requirements established by NBR 9050 (2015) and the Brazilian Association of Technical Standards (ABNT). This kind of assistance is very important, and can even a determining factor in the choice of tourist destination (Tourism Ministry, 2016).

\section{REFERENCES}

ABNT, N. B. (2015). ABNT NBR 9050. Rio de Janeiro.

Alves, A. (2016). Ministério do Turismo. Turismo depois dos 60 anos. Available at http:// www.turismo.gov.br/ultimas-noticias/7137-turismodepois-dos-60.html. Accessed on May 19, 2020

Beni, Mário Carlos (2001). Análise estrutural do turismo. São Paulo: SENAC. 
ABNT, N. B. (2015). ABNT NBR 9050. Rio de Janeiro.

Alves, A. (2016). Ministério do Turismo. Turismo depois dos 60 anos. Available at http:// www.turismo.gov.br/ultimas-noticias/7137-turismodepois-dos-60.html. Accessed on May 19, 2020

Beni, Mário Carlos (2001). Análise estrutural do turismo. São Paulo: SENAC.

Brambilla, A., Vanzella, E., \& Baptista, M. M. (2012). TURISMO CULTURAL NA CIDADE DE JOÃO PESSOA: um olhar focado no turista.

Brasil, Ministério do Turismo. (2016). Ministério do Turismo - Cartilha do idoso - Dicas para atender bem turista idoso: Acesso em 23 de Janeiro de 2019, available at http://www.turismo.gov.br/images/ pdf/27_09_2016_cartilha_idoso.pdf

Brasil, Ministério do Turismo (2014). Ministério do Turismo - Portal do envelhecimento, Viaja mais. Accessed in 2018, available at : http:// www.portaldoenvelhecimento.com/turismo/item/3332 -viaja_mais_melhor_idade

Brasil, Ministério do Turismo (2008). Turismo de sol e praia: orientações básicas. / Ministério de Turismo, Coordenação Geral de Segmentação; Coordenação Geral de Jurema Monteiro. - Brasília: Ministério do Turismo, 2008.

Evangelista, G. P., Brambilla, A., \& Vanzella, E. (2018). Acessibilidade para Idosos: Um Estudo Aplicado ao Theatro Santa Roza. In: A. Brambilla, E. Vanzella, \& M. F. Silva, T \& H - Turismo e Hotelaria no Contexto da Acessibilidade (pp. 248 - 279). João Pessoa: Editora do CCTA.

Evangelista, G. P., Brambilla, A., \& Vanzella, E. (jul/dez de 2019). Acessibilidade para a terceira idade: um estudo aplicado a Igreja da SantaCasa de Misericórdia da Paraíba. EDUCERE, X.

Kaiser, B. (2006). O geógrafo e a pesquisa de campo. Boletim Paulista de Geografia (84), 93-104.

Lohmann, G.; Panosso Netto, A. (2012). Teoria do turismo : conceitos, modelos e sistemas. 2. ed. São Paulo : Aleph

Malhotra, N. K. (2011). Pesquisa de marketing (6 ed.). Bookman.

Melo, P. F., Vanzella, E., \& Brambilla, A. (2019). Turismo de Sol e Praia: um estudo sobre acessibilidade para a terceira idade na Praia da Penha - João
Pessoa. VI Congresso Internacional de Envelhecimento Humano - Anais.

Mendonça, J., Barbosa, M., \& Durão, A. (2007). Fotografias como um recurso de pesquisa em marketing: o uso de métodos visuais no estudo de organizações de serviços. Scielo, 11.

Oliveira, A. P. (2001). Turismo e desenvolvimento: planejamento e organização. São Paulo: Atlas.

Ruschmann, D. V. D. M.; Solha, T. (2012). Turismo e laser para a pessoa idosa. Baruerí - SP: Manole.

Shimosakai, R. (2 de outubro de 2016). Turismo adaptado. Acesso em 10 de abril de 2020, Available at https://ricardoshimosakai.com.br/dia-mundial-doturismo-acessibilidade-e-o-tema-do-ano-confira/

Vanzella, E.(2019) O impacto nos gastos com internações da população idosa, nas capitais brasileiras, em razão da migração da população idosa. João Pessoa: Editora do CCTA. 


\section{APPENDICES}

Figure 1: vertical and ground-level signage

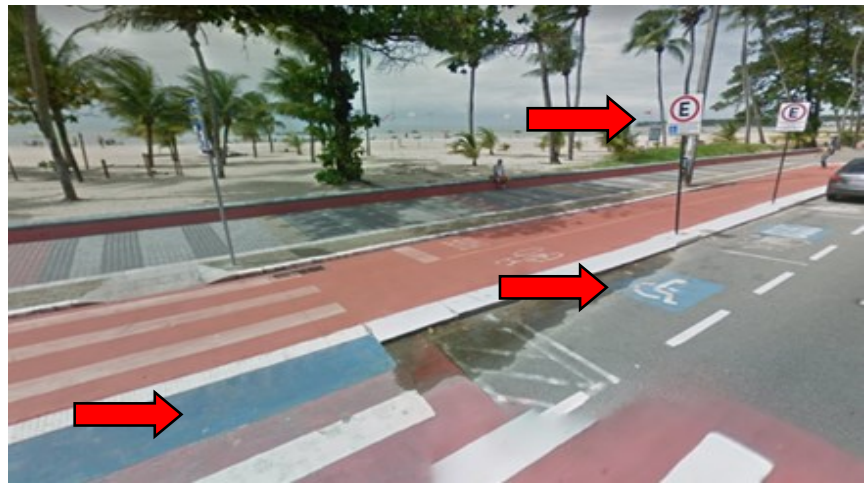

Source: MELO, 2019.

Figure 2: absence of tactile floor

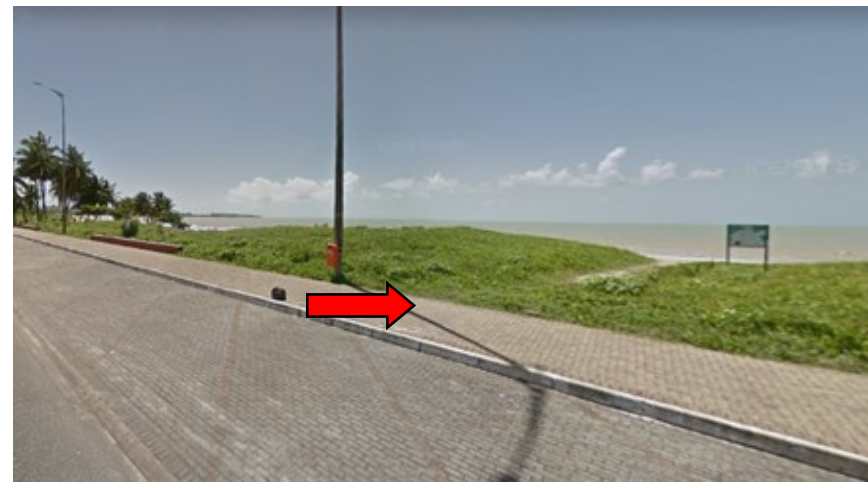

Source: MELO, 2019.

Figure 3: guide for wheelchair users without any crosswalk

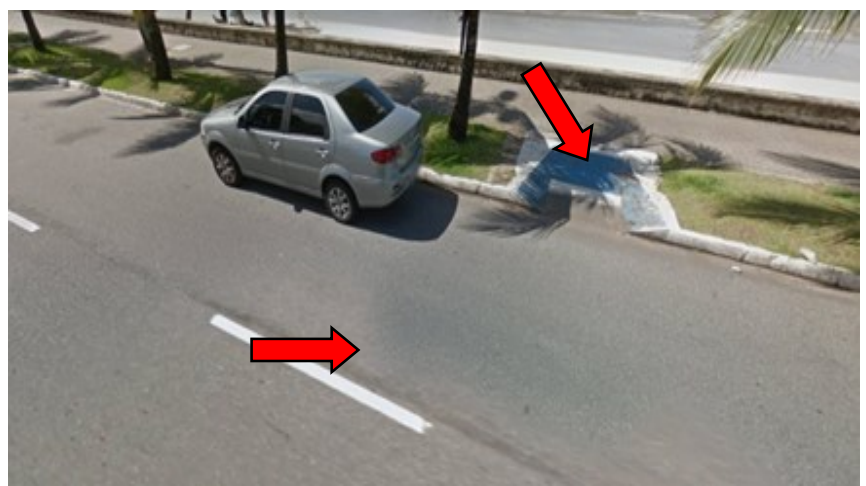

Source: MELO, 2019.
Figure 4: tactile paving

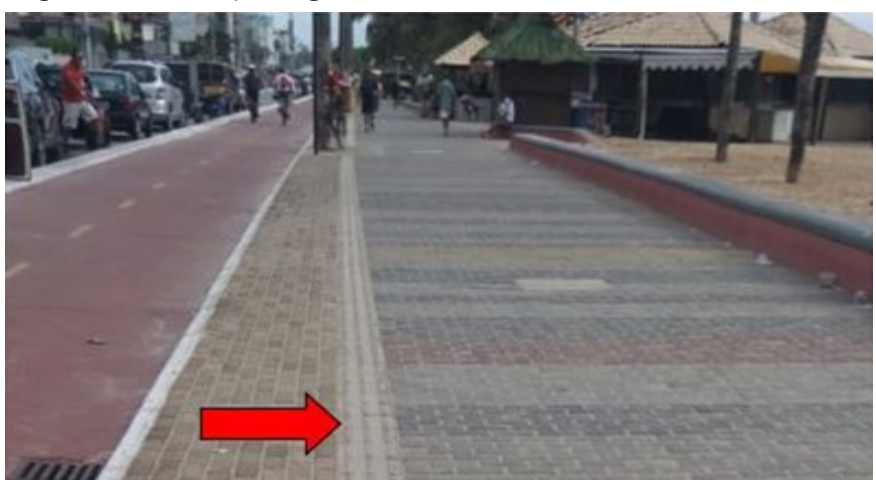

Source: MELO, 2019.

Figure 5: ramp for people with wheelchairs

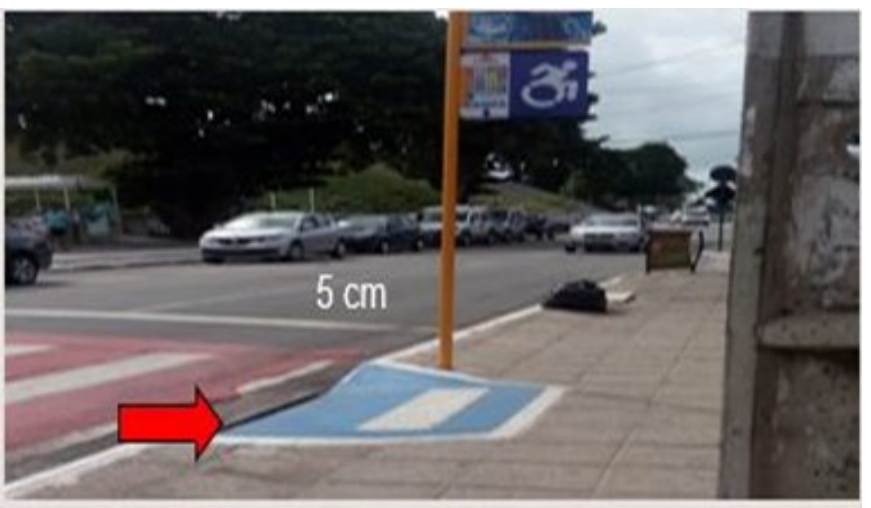

Source: MELO, 2019.

Figure 6: pole near the tactile paving

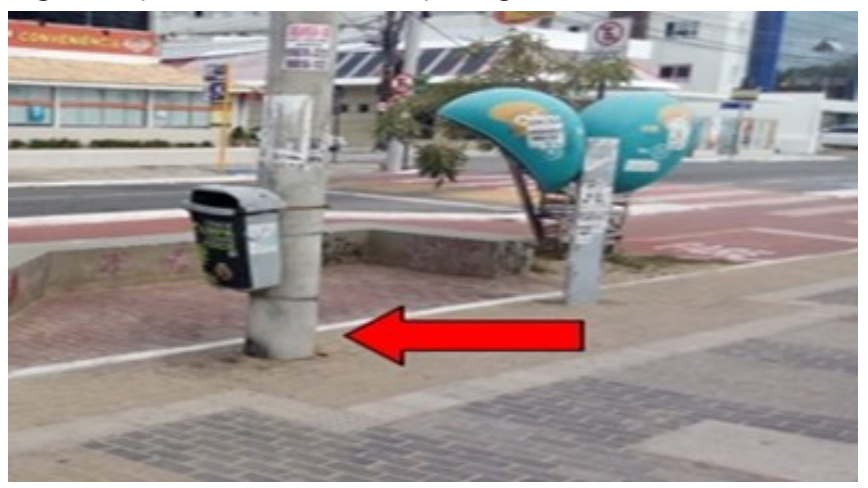

Source: MELO, 2019. 


\section{INSPECTION SCHEDULE \\ ACCESSIBILITY CHECK OF THE PUBLIC PROMENADE}

VERIFICATION CHECKLIST

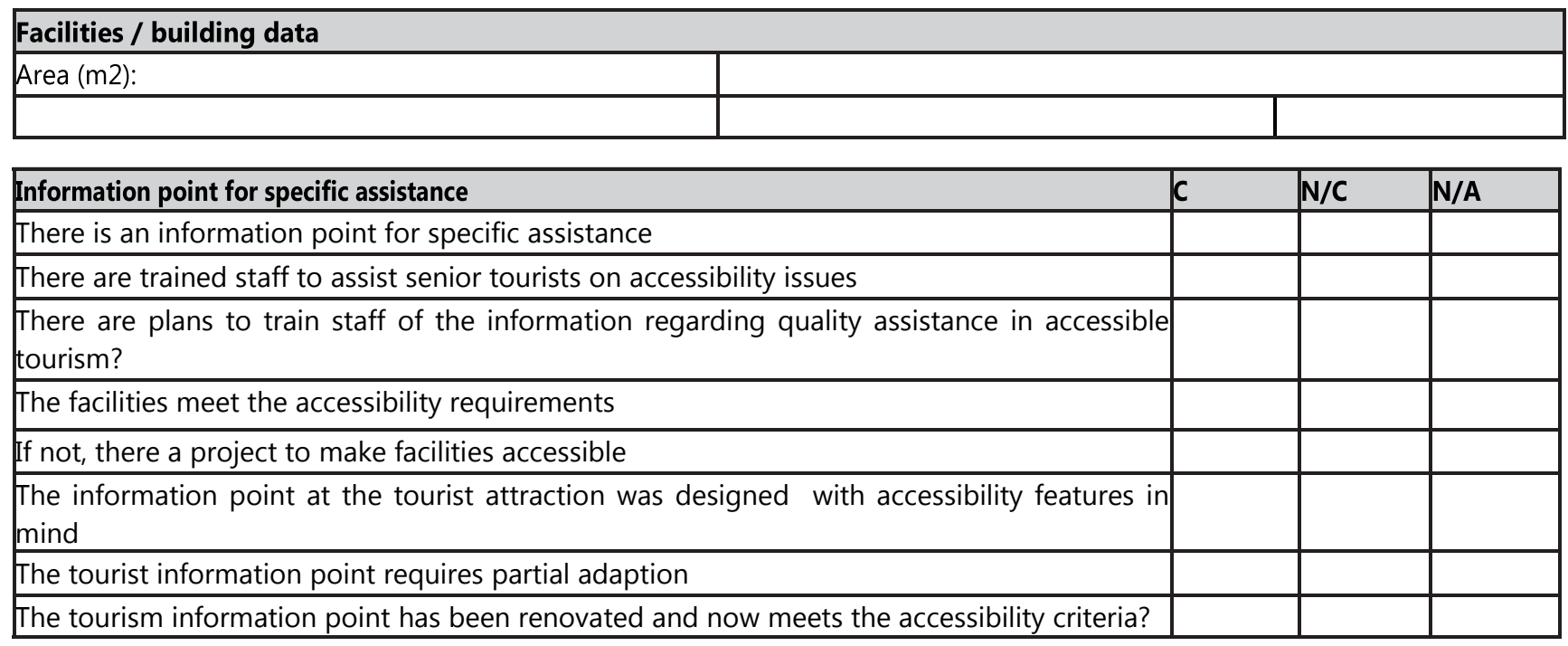

\begin{tabular}{|c|c|c|c|}
\hline Acess spots & $\mathbf{C}$ & $\mathrm{N} / \mathrm{C}$ & N/A \\
\hline \multicolumn{4}{|l|}{ Surfaces are regular } \\
\hline \multicolumn{4}{|l|}{ The sidewalk is at least $1.20 \mathrm{~m}$ in width } \\
\hline \multicolumn{4}{|l|}{ The sidewalk in good condition } \\
\hline \multicolumn{4}{|l|}{ There is tactile paving } \\
\hline \multicolumn{4}{|l|}{ There is hazard warning tactile paving } \\
\hline \multicolumn{4}{|l|}{ There is directional guidance tactile paving } \\
\hline \multicolumn{4}{|l|}{ There is anti-slip paving } \\
\hline \multicolumn{4}{|l|}{ The paving is slippery } \\
\hline \multicolumn{4}{|l|}{ The floor vibrates } \\
\hline \multicolumn{4}{|l|}{ There is anti-vibration paving } \\
\hline \multicolumn{4}{|l|}{ There are ramps } \\
\hline \multicolumn{4}{|l|}{ The ramps are accessible } \\
\hline \multicolumn{4}{|c|}{ There are uneven surfaces in the accessible route } \\
\hline \multicolumn{4}{|l|}{ There are obstacles in the accessible route } \\
\hline \multicolumn{4}{|l|}{ Obstacles are clearly signposted } \\
\hline \multicolumn{4}{|l|}{ There are lowered curbs } \\
\hline \multicolumn{4}{|l|}{ Lowered curbs are accessible } \\
\hline \multicolumn{4}{|l|}{ There are painted and lightning crosswalks } \\
\hline \multicolumn{4}{|c|}{ There are crosswalks with signaling and protruding strips } \\
\hline \multicolumn{4}{|l|}{ There are steps } \\
\hline \multicolumn{4}{|l|}{ There is tactile flooring on steps } \\
\hline \multicolumn{4}{|l|}{ There is an accessible ramp close to steps } \\
\hline Steps and ramps have guardrails (handrails) & & & \\
\hline
\end{tabular}




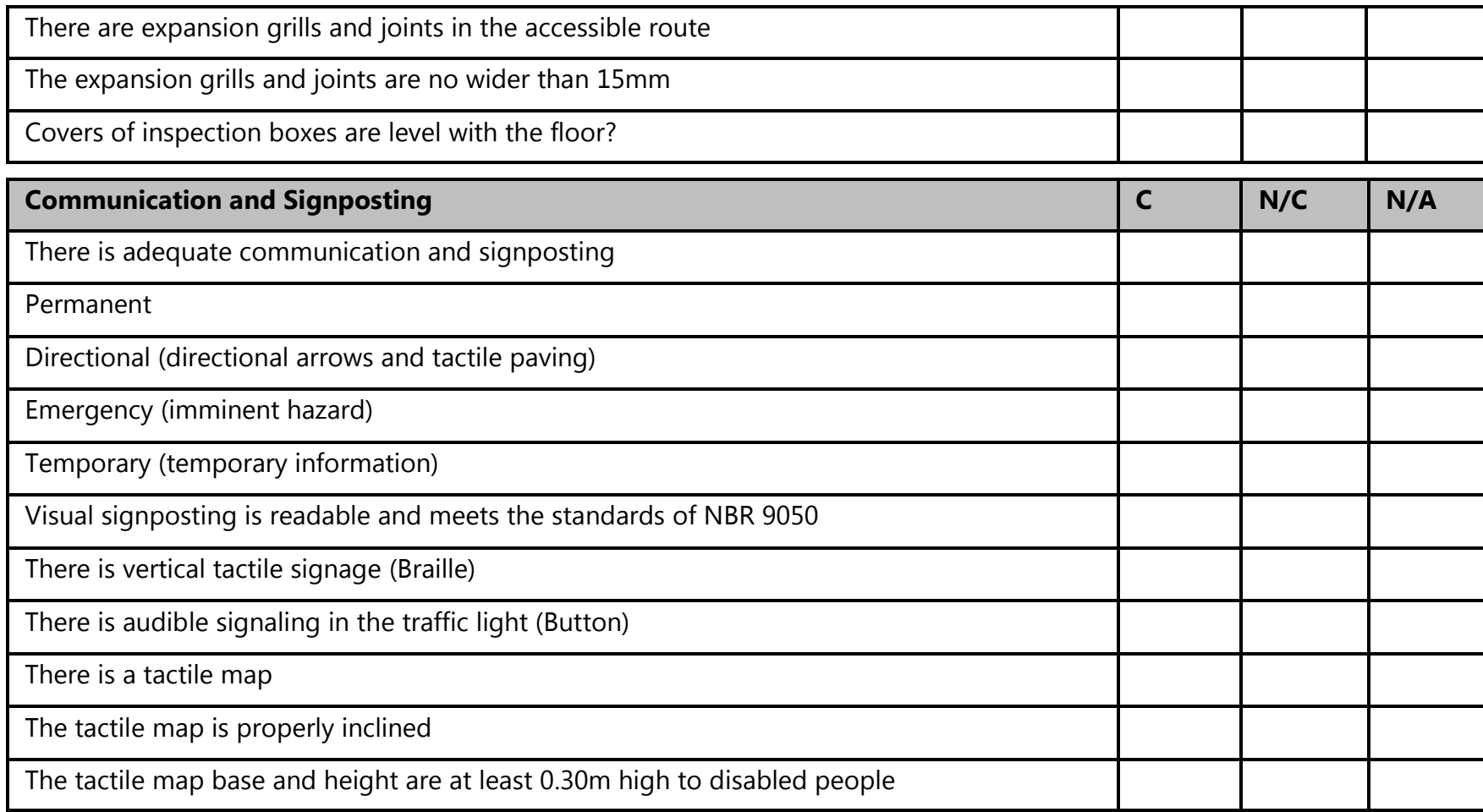

\begin{tabular}{|c|c|c|c|}
\hline Parking spaces & $\mathbf{C}$ & $\mathrm{N} / \mathrm{C}$ & N/A \\
\hline There is the minimum number required by law & & & \\
\hline Parking spaces have ground-level accessible signs & & & \\
\hline Parking spaces have vertical accessible signage & & & \\
\hline The parking spaces are at least $1.20 \mathrm{~m}$ in width & & & \\
\hline They are linked to accessible routes & & & \\
\hline Their location avoids circulation between vehicles & & & \\
\hline
\end{tabular}

\begin{tabular}{|c|c|c|c|}
\hline Toilets & $\mathbf{C}$ & $\mathrm{N} / \mathrm{C}$ & N/A \\
\hline \multicolumn{4}{|c|}{ They are located on an inaccessible route } \\
\hline \multicolumn{4}{|c|}{ There is the minimum number required by law (5\%) } \\
\hline \multicolumn{4}{|l|}{ There are handrails } \\
\hline \multicolumn{4}{|l|}{ There are accessible urinals } \\
\hline Doors are at least $1.00 \mathrm{~m}$ in width & & & \\
\hline
\end{tabular}

\begin{tabular}{|c|c|c|c|}
\hline Beaches & $\mathbf{C}$ & N/C & N/A \\
\hline \multicolumn{4}{|l|}{ There are accessible ramps leading to the sea } \\
\hline \multicolumn{4}{|c|}{ Ramps are signposted with the international access symbol } \\
\hline \multicolumn{4}{|c|}{ There are accessible unisex restrooms close to the adapted access areas } \\
\hline \multicolumn{4}{|l|}{ There are phone booths } \\
\hline \multicolumn{4}{|l|}{ There are accessible phone booths } \\
\hline \multicolumn{4}{|c|}{ There is a reference module besides the fixed seats of the accessible routes } \\
\hline \multicolumn{4}{|c|}{ The reference module is located properly, and does not affect free circulation } \\
\hline There are accessibility adaptable benches & & & \\
\hline
\end{tabular}




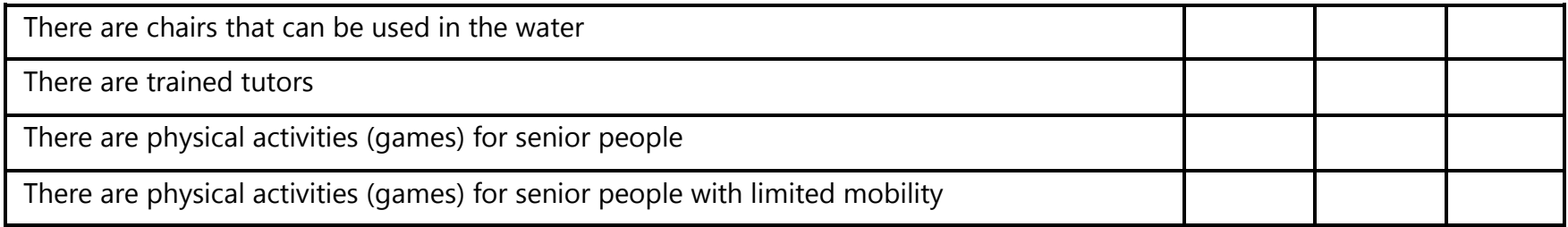

